\title{
Non-Selectivity of R-S Media for Aeromonas hydrophila and TCBS Media for Vibrio Species Isolated from Diseased Oreochromis niloticus
}

\author{
Ibrahim M Aboyadak ${ }^{1 *}$, Nadia GM Ali ${ }^{1}$, Ashraf MAS Goda ${ }^{2}$, Walaa Saad ${ }^{3}$ and Asmaa ME Salam ${ }^{4}$ \\ ${ }^{1}$ Fish Disease Lab, National Institute of Oceanography and Fishery (NIOF), Egypt \\ ${ }^{2}$ Aquaculture Division, National Institute of Oceanography and Fishery (NIOF), Egypt \\ ${ }^{3}$ Central Diagnostic and Research Lab, Faculty of Veterinary Medicine, Kafrelsheikh University, Egypt \\ ${ }^{4}$ Faculity of Aquatic and Fisheries Sciences, Kafrelsheikh University, Egypt
}

\begin{abstract}
The current study was conducted to determine the bacterial pathogens incorporated in mass mortality observed in cultured Oreochromis niloticus farms at Kafrelsheikh province, Egypt, during the summer season of 2015. Moribund fish samples were collected from six infected farms. General signs of septicemia were dominant in the clinical and gross internal examination of diseased fish. The pathogenic bacteria were isolated on specific media then confirmed by polymerase chain reaction (PCR). Out of thirty isolates, nineteen Aeromonas hydrophila, seven Vibrio cholera and three Vibrio alginolyticus isolates were recovered and identified using PCR. Current study indicated non-selectivity of Rimler-Shotts media for selective isolation of Aeromonas hydrophila also non-selectivity of TCBS media for Vibrio spp. isolated from diseased Oreochromis niloticus.
\end{abstract}

Keywords: Aeromonas; Vibrio alginolyticus; Vibrio cholera; PCR.

\section{Introduction}

Fish is cheap delicious animal protein of high nutritive value; it represents a good substitute to red meet especially in developing countries. Expanding in global aquaculture help to provide the excessive demand by increased human population. Finfish production comprised 49.8 million tons, (99.2 billion USD), Egypt ranked as the $8^{\text {th }}$ aquaculture producing country in 2014 [1], it is producing about 1.130 .000 ton of finfish that representing $2.26 \%$ of global aquaculture of these species. Egypt also, ranked as the second global tilapia producer after China, it produces about 867557 tons in 2014 [2]

Economic losses from diseases outbreaks in global aquaculture estimated by 3 Billion USD in 1997 [3]. Bacterial diseases reported to be the main etiological agents responsible for severe economic losses in cultured fish, including infection with Aeromonas spp., Pseudomonas spp., Vibrio spp., Streptococcus spp. and Enterococcus spp. as recorded by Aboyadak et al. [4], Zhang et al. [5], Olugbojo and Ayoola [6], Darak and Barde [7], Thune et al. [8]

Bacterial fish diseases resulted in various clinical finding including skin hemorrhage, ascites and exophthalmia [9-11]. Enlarged congested internal organs including liver spleen and kidney, and intestinal hemorrhage with or without presence of ascetic fluid in abdominal cavity are the main internal lesions [12-14]

The genus Vibrio is a member of the family Vibrionaceae, it is a Gram negative non-spore forming comma shape rods. Thiosulphate citrate bile salt sucrose (TCBS) agar is highly selective for the isolation of $V$. cholerae and another Vibrio spp. The acidification of the medium resulting from the fermentation of sucrose by Vibrio makes bromthymol blue turns yellow.

The genus Aeromonas is belongs to the family Aeromonadaceae, it is a Gram negative facultative anaerobic cocco-bacilli. Rimler-Shotts (RS) agar used for selective isolation and identification of Aeromonas hydrophila, the organisms that ferment maltose are seen as yellow colonies.

Isolation and biochemical identification of pathogenic bacteria are laborious and time consuming, application of molecular methods such as the polymerase chain reaction (PCR), is an easy, less expensive, and more rapid means for diagnosis of such diseases $[15,16]$.
The present work was conducted to determine the bacterial pathogens responsible for mass mortality in cultured tilapia farms at Kafrelsheikh province using selective media and polymerase chain reaction.

\section{Materials and Methods}

\section{Study area}

Samples were taken from six affected tilapia farms at Torombat seven, Alreiad district, Kafrelsheikh governorate northern Egypt. The affected farms complain increased mortality during the study period from March to August 2015.

\section{Samples}

Thirty live diseased Nile tilapias (Oreochromis niloticus) with obvious signs of septicemia were collected; five fish were taken from each farm. Diseased fish weight was ranged between 100-250 g and 16-24 cm in total body length. Each fish sample was packed alive in a separate sterile labeled plastic bag and transported in ice pox to lab.

\section{Clinical examination}

The clinical examination including observation of any external lesions was performed according to the method described by Noga [13].

\section{Post mortem examination}

The post mortem examination was performed according to the method described by Heil [17].

*Corresponding author: Ibrahim M. Aboyadak, Fish Disease Lab, National Institute of Oceanography and Fishery (NIOF), Egypt, Tel: 00201005100472; E-mail: i.aboyadak@gmail.com

Received July 13, 2017; Accepted August 02, 2017; Published August 04, 2017

Citation: Aboyadak IM, Ali NGM, Goda AMAS, Saad W, Salam AME (2017) NonSelectivity of R-S Media for Aeromonas hydrophila and TCBS Media for Vibrio Species Isolated from Diseased Oreochromis niloticus. J Aquac Res Development 8: 496. doi: 10.4172/2155-9546.1000496

Copyright: ( $) 2017$ Aboyadak IM, et al. This is an open-access article distributed under the terms of the Creative Commons Attribution License, which permits unrestricted use, distribution, and reproduction in any medium, provided the original author and source are credited. 
Citation: Aboyadak IM, Ali NGM, Goda AMAS, Saad W, Salam AME (2017) Non-Selectivity of R-S Media for Aeromonas hydrophila and TCBS Media for Vibrio Species Isolated from Diseased Oreochromis niloticus. J Aquac Res Development 8: 496. doi: 10.4172/2155-9546.1000496

Page 2 of 5

\section{Isolation and identification of the causative agent}

Under complete aseptic condition, a small tissue pieces from heart, hepatopancreas, spleen, posterior kidney and from lesions in musculature were taken from each fish to a labeled test tube containing $10 \mathrm{ml}$ sterile peptone water, after that the sample was homogenized at 3000 rounds per minute (rpm) for 1 min using homogenizer pro ${ }^{\circ}$ USA. Test tubes were centrifuged at $500 \mathrm{rpm}$ for $30 \mathrm{sec}$ and one $\mathrm{ml}$ from supernatant was added to another test tube containing sterile tryptic soy broth then incubated at $33^{\circ} \mathrm{C}$ for $24 \mathrm{~h}$. Rimler-Shotts media with novobiocin selective supplement (HiMedia, India), tryptic soy agar (Oxoid, England), Pseudomonas selective agar with CFC (Cetrimide - Fucidin - Cephaloridine) and glycerol supplement, (Lab M, United Kingdom), TCBS agar media (Oxiod, England) and Edwards media modified (Oxiod, England) were streaked from each sample then incubated at $33^{\circ} \mathrm{C}$ for $24 \mathrm{~h}$. Few morphologically similar colonies from isolates grown on each media were picked up and inoculated to trypticase soy broth, incubated at $33^{\circ} \mathrm{C}$ for $24 \mathrm{~h}$ then $0.5 \mathrm{ml}$ from this broth was preserved on sterile $50 \%$ glycerol (biotechnology grade) one volume from overnight broth : one volume from $50 \%$ glycerol, after that it was stored on $-80^{\circ} \mathrm{C}$ for - PCR identification.

\section{Identification of collected strains using PCR}

DNA extraction: Bacterial DNA extraction was performed by thermolysis based on destruction of bacterial cells using dry heat as described by Ahmed et al. [18]. Two hundred microliter of overnight cultured broth was mixed with $800 \mu$ l of nuclease free double deionized distilled water in eppendorf tube, after that the eppendorf tubes were placed in heat block for $5 \mathrm{~min}$ at $95^{\circ} \mathrm{C}$ followed by cool centrifugation for $2 \mathrm{~min}$ at $15000 \mathrm{rpm}$ and $4^{\circ} \mathrm{C}$, the supernatant was used as DNA template and stored at $-20^{\circ} \mathrm{C}$ for PCR study.

\section{Primers}

Primers used for identification of recovered isolates shown in (table 1).

\section{PCR procedures}

PCR mixture for amplification of targeted DNA: The reaction volume for all performed PCR reaction was $25 \mu$, each reaction volum consists of $5 \mu \mathrm{l}$ of $5 \mathrm{X}$ master mix (taql/high yield- Jena Bioscience, Jena, Germany, consists of DNA polymerase, dNTPs mixture, (NH4) SO4, $\mathrm{MgCl} 2$, Tween 20 , Nonidet P-40, stabilizers $)+1.25 \mu \mathrm{l}$ of each primer (forward and reverse) $(20 \mathrm{pmol} / \mu \mathrm{l}),+5 \mu \mathrm{l}$ of extracted bacterial DNA + $12.5 \mu \mathrm{l}$ of nuclease free double deionized distilled water. Amplification of targeted DNA gens was carried out in thermal cycler (T100TM Thermal cycler, BIORAD, USA).

A- Thermal cycle adjustment for amplification of genus Aeromonas and Aeromonas hydrophyla target DNA: Amplification of genus Aeromonas targeted DNA was performed according to the method described by Lee et al. [19], with an initial denaturation at $94^{\circ} \mathrm{C}$ for $4 \mathrm{~min}$ followed by 35 cycles of denaturation each at $94^{\circ} \mathrm{C}$ for $1 \mathrm{~min}$, annealing at $68^{\circ} \mathrm{C}$ for $30 \mathrm{sec}$ and extension steps at $72^{\circ} \mathrm{C}$ for $45 \mathrm{secs}$, then final extension step at $72^{\circ} \mathrm{C}$ for $10 \mathrm{~min}$.

Amplification of Aeromonas hydrophila targeted DNA (specific-16S rRNA gene) was done using the same primer described by Trankhan et al. [20] but with different PCR condition. The thermal cycler condition was adjusted as following: initial denaturation at $94^{\circ} \mathrm{C}$ for $2 \mathrm{~min}$, followed by 35 cycles of denaturation, at $94^{\circ} \mathrm{C}$ for 30 secs, annealing at $55.5^{\circ} \mathrm{C}$ for $30 \mathrm{sec}$ and extension steps at $72^{\circ} \mathrm{C}$ for $30 \mathrm{secs}$, then one final extension step at $72^{\circ} \mathrm{C}$ for $10 \mathrm{~min}$.

B- Thermal cycle adjustment for amplification of genus Vibrio, Vibrio cholera, Vibrio parahaemolyticus and Vibrio alginolyti-
Table 1: Primers used for detection of Genus Aeromonas and Aeromonas hydrophila, Genus Vibrio, Vibrio cholera, Vibrio parahaemolyticus and Vibrio alginolyticus.

\begin{tabular}{|c|c|c|c|}
\hline $\begin{array}{l}\text { Target bac- } \\
\text { teria }\end{array}$ & Primer Name & Oligonucleotide Sequence $\left(5^{\prime}-3^{\prime}\right)$ & $\begin{array}{l}\text { Size } \\
\text { (Bp) }\end{array}$ \\
\hline \multirow{2}{*}{$\begin{array}{c}\text { Genus } \\
\text { Aeromonas }\end{array}$} & AER-F & CTA CTT TTG CCG GCG AGC GG & \multirow{2}{*}{$953 \mathrm{bp}$} \\
\hline & AER-R & TGA TTC CCG AAG GCA CTC CC & \\
\hline \multirow{2}{*}{$\begin{array}{l}\text { A. hy- } \\
\text { drophila }\end{array}$} & 16SrRNA-F & GGC CTT GCG CGA TTG TAT AT & \multirow{2}{*}{$103 \mathrm{bp}$} \\
\hline & 16SrRNA-R & GTG GCG GAT CAT CTT CTC AGA & \\
\hline \multirow{2}{*}{$\begin{array}{l}\text { Genus } \\
\text { Vibrio }\end{array}$} & 16SrRNA-F & CCT GGT AGT CCA CGC CGT AA & \multirow{2}{*}{$168 \mathrm{bp}$} \\
\hline & 16SrRNA-R & CGA ATT AAA CCA CAT GCT CCA & \\
\hline \multirow{2}{*}{ V. cholera } & OmpW-F & CAC CAA GAA GGT GAC TTT ATT GTG & \multirow{2}{*}{$427 \mathrm{bp}$} \\
\hline & OmpW-R & CGT TAG CAG CAA GTC CCC AT & \\
\hline \multirow{2}{*}{$\begin{array}{c}\text { V. } \\
\text { parahaemo- } \\
\text { lyticus }\end{array}$} & Collagenase-F & GAA AGT TGA ACA TCA TCA GCA CGA & \multirow{2}{*}{$271 \mathrm{bp}$} \\
\hline & Collagenase-R & GGT CAG AAT CAAACG CCG & \\
\hline \multirow{2}{*}{$\begin{array}{l}\text { V. alginolyti- } \\
\text { cus }\end{array}$} & GyrB-F & GAG AAC CCG ACA GAA GCG AAG & \multirow{2}{*}{$337 \mathrm{bp}$} \\
\hline & GyrB-R & CCT AGT GCG GTG ATC AGT GTT G & \\
\hline
\end{tabular}

cus target DNA: Thermal cycler adjustment for amplification of genus Vibrio and mentioned Vibrio species targeted DNA were the same, it performed according to the method described by Wei et al. [15] except, reaction for each species was performed separately (not multiplex). Amplification starts with an initial denaturation at $94^{\circ} \mathrm{C}$ for $3 \mathrm{~min}$, followed by 30 cycles of (denaturation at $94^{\circ} \mathrm{C}$ for 30 s, annealing at $60^{\circ} \mathrm{C}$ for $30 \mathrm{~s}$, and extension step at $72^{\circ} \mathrm{C}$ for $120 \mathrm{~s}$ ), finishing with a final extension step at $72^{\circ} \mathrm{C}$ for $10 \mathrm{~min}$ then storage at $4^{\circ} \mathrm{C}$.

\section{DNA assay}

DNA was assayed by agarose gel-electrophoresis, $5 \mu \mathrm{l}$ from the PCR products were loaded in $1.5 \%$ agarose $0.6 \mu \mathrm{g} / \mathrm{ml}$ ethidium bromide in $1 \mathrm{X}$ tris acetate EDTA buffer using gel electrophoresis apparatus (SCIEPLAS, UK). DNA bands were visualized using UV transilluminator (Winpact Scientific, USA).

\section{Results and Discussion}

Bacterial infections represent the major cause of economic losses in fish farms [21]. The recorded mortality in affected farms was $8 \%$ to $15 \%$ during 2 weeks after disease onset (appearance of clinical signs as daily mortality was $0.5 \%$ to $1 \%$ ) which considered direct economic losses due to bacterial infection.

General signs of septicemia including presence of hemorrhagic patches on the skin and at the base of pectoral fin together with scale desquamation and skin ulceration were the most common observed signs (Figure 1). Increase the abdomen size (ascites), (Figure 1) and exophthalmia was occasionally observed in diseased fish. Congestion of internal organs with enlarged liver and enlarged gall bladder (Figure 1), congested stomach walls and intestine was the dominant postmortem lesion (Figure 1). Similar clinical and post mortem finding was observed by Asaad [22], Zakaria [23], Laith and Najiah [24] and Zhang et al. [5] in naturally infected fish with Aeromonas hydrophyla. The same clinical finding was also observed in naturally infected Oreochromis niloticus with different Vibrio species as described by Chen et al. [25] and Okasha et al. [26].

Isolated bacterial pathogens express their effect through different virulence factors. Aeromonas hydrophila release a variety of virulence factors which are important for their pathogenicity [27], these virulence factors including outer membrane protein, extracellular products (cytotoxins and proteases) and enterotoxins [12,28]. Pathogenic Vibrio species produce a wide variety of proteases and extracellular enzymes 
Citation: Aboyadak IM, Ali NGM, Goda AMAS, Saad W, Salam AME (2017) Non-Selectivity of R-S Media for Aeromonas hydrophila and TCBS Media for Vibrio Species Isolated from Diseased Oreochromis niloticus. J Aquac Res Development 8: 496. doi: 10.4172/2155-9546.1000496

Page 3 of 5

that capable of causing tissue and cell damage in infected fish, purified Vibrio proteinases are toxic to fish [8], Vibrio cholera is a highly virulent fish pathogen, [29], it has the ability to bind collagen, fibrinogen, gelatin, and fibronectin and have specific surface receptors for connective tissue [30]. Haemolysins and toxic proteases produced by Vibrio alginolyticus play great role in pathogenicity [31].

Out of thirty sample twenty-two isolate grow on R-S media producing yellow colonies which is specific for Aeromonas hydrophyla (Figure 1) while on TCBS media fourteen isolate grow giving yellow colonies (Figure 1) specific for genus Vibrio and none of the thirty isolates growth over Pseudomonas selective agar or modified Edwards media. Only one sample not grows on any of previously mentioned specific media.

Results of growth on specific media was controversial, as 7 bacterial isolates grow on both R-S and TCBS media in the same time that means either presence of mixed infection between Aeromonas and Vibrio in the same sample or ability of some strains to grow on both media in the same time, and to determine any of these possibilities is true all the recovered yellow colonies grow on Rimler-Shotts media were subjected to PCR identification for genus Aeromonas and for genus Vibrio, and so for all isolates recovered on TCBS were subjected to PCR identification for genus Vibrio and for genus Aeromonas.

PCR identification results become more obvious, out of twenty-two isolate grow on Rimler-Shotts media nineteen isolate was positive for genus Aeromonas and all of them are Aeromonas hydrophyla, and three isolates were positive for genus Vibrio (Table 2) after that these threeVibrio species were identified by PCR as two Vibrio alginolyticus isolates and one Vibrio cholera isolates.
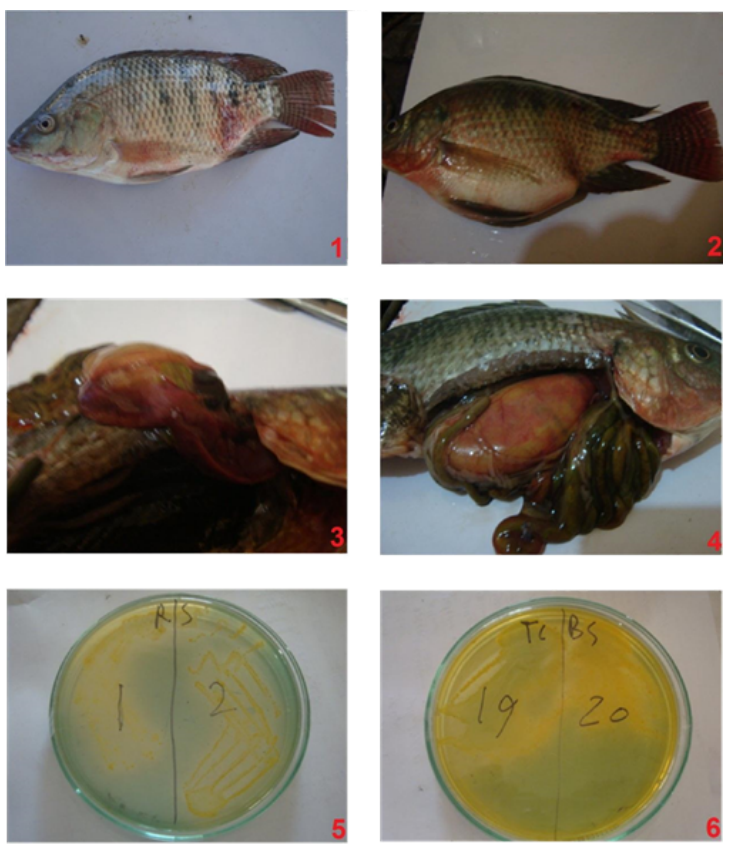

Figure 1: (1) Naturally infected Oreochromis niloticus showing scale desquamation, skin ulceration and hemorrhage. (2) Naturally infected Oreochromis niloticus showing abdominal distention with presence of hemorrhagic patches at caudal peduncle. (3) Naturally infected Oreochromis niloticus showing inflamed and severely congested hepatopancreas with presence of hemorrhagic patches. (4) Naturally infected Oreochromis niloticus showing inflamed and congested stomach and intestine. (5) R-S media with novobiocin selective supplement showing characteristic yellow colonies of Aeromonas hydrophyla. (6) TCBS media showing yellow colonies of Vibrio cholera and Vibrio alginolyticus.
Table 2: Number of clinically diseased fish samples and recovered bacterial isolates.

\begin{tabular}{|c|c|c|}
\hline $\begin{array}{c}\text { Number of affected } \\
\text { farms }\end{array}$ & $\begin{array}{c}\text { Number of clinically } \\
\text { diseased } \\
\text { fish samples }\end{array}$ & $\begin{array}{c}\text { Number of recovered } \\
\text { bacterial } \\
\text { isolates }\end{array}$ \\
\hline 6 & 30 & 30 \\
\hline $\begin{array}{c}\text { No. of isolates grown } \\
\text { on R-S } \\
\text { media }\end{array}$ & $\begin{array}{c}\text { No. of isolates grown on } \\
\text { R-S, identified as genus } \\
\text { Aeromonas by PCR }\end{array}$ & $\begin{array}{c}\text { No. of isolates grown } \\
\text { on R-S, identified as } \\
\text { genus Vibrio by PCR }\end{array}$ \\
\hline 22 & 19 & 3 \\
\hline $\begin{array}{c}\text { No. of isolates grown } \\
\text { on TCBS } \\
\text { media }\end{array}$ & $\begin{array}{c}\text { No. of isolates grown } \\
\text { on TCBS, identified as } \\
\text { genus Vibrio by PCR }\end{array}$ & $\begin{array}{c}\text { No. of isolates grown } \\
\text { on TCBS, identified as } \\
\text { genus Aeromonas by } \\
\text { PCR }\end{array}$ \\
\hline 14 & 10 & 4 \\
\hline
\end{tabular}
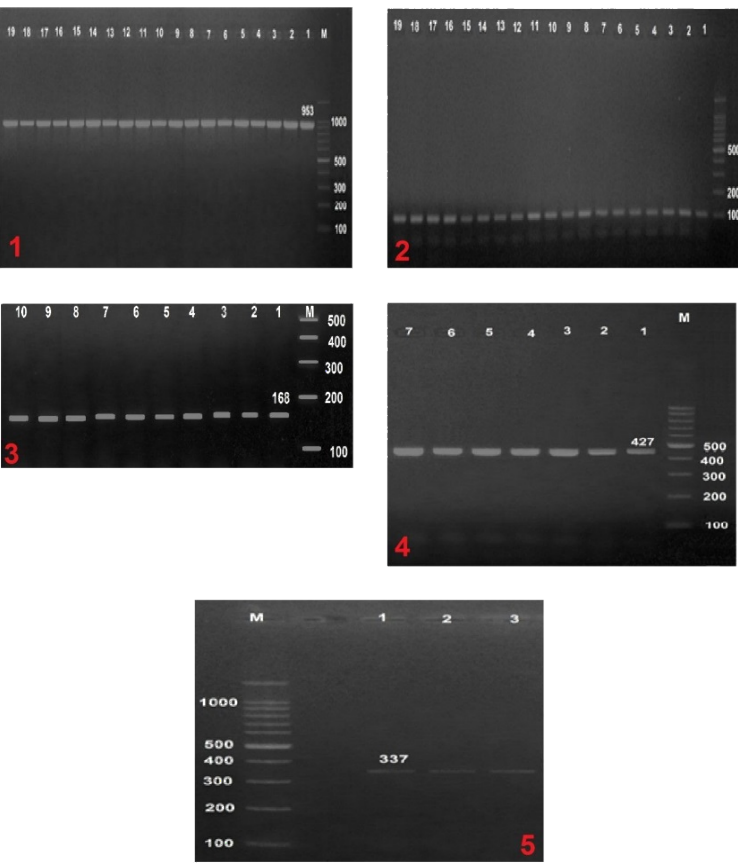

Figure 2: (1) Agarose gel electrophoresis of PCR product showing specific genus Aeromonas bands at $953 \mathrm{bp}$. (2) Agarose gel electrophoresis of PCR product showing specific Aeromonas hydrophyla bands at $103 \mathrm{bp}$. (3) Agarose gel electrophoresis of PCR product showing specific genus vibrio bands at 168 bp. (4) Agarose gel electrophoresis of PCR product showing specific Vibrio cholere bands at $427 \mathrm{bp}$. (5) Agarose gel electrophoresis of PCR product showing specific Vibrio alginolyticus bands at $337 \mathrm{bp}$.

PCR identification for fourteen isolates grown on TCBS indicating presence of only ten isolates were positive for genus Vibrio, from them seven isolates were Vibrio cholera, and three was Vibrio alginolyticus and Vibrio parahaemolyticus. While the remaining four isolates identified as Aeromonas hydrophyla (Table 2).

PCR is a rapid and specific molecular technique provide a highly accurate results, amplification of $16 \mathrm{~S}$ rRNA gene fragment indicated presence of nineteen Aeromonas sp. Isolate that characterized by appearance of specific bands at $953 \mathrm{bp}$, all these isolates were further identified by PCR as Aeromonas hydrophyla as characteristic bands appeard at $103 \mathrm{bp}$ (Figure 2). Other researches indicating identification of such genus and species using the same primers design including Lee et al. [19] and Zakaria [23] for genus areomonas and Trankhan et al. [20] and Aboyadak et al. [4] for Aeromonas hydrophyla.

Agar gel electrophoresis of PCR product for detection genus Vibrio 
and its different species revealed detection of ten isolates related to genus Vibrio at 168 bp by amplification of $16 \mathrm{~S}$ rRNA gene (Figure 2), seven isolates were identified as Vibrio cholera at 427 bp through amplification of OmpW gene (Figure 2) and three isolates were identified as Vibrio alginolyticus at $337 \mathrm{bp}$ through amplification of GyrB gene (Figure 2). In current research, no isolates were identified as Vibrio parahaemolyticus. Wei et al. [32] and Wei et al. [15] recorded the same results using the same primers but different thermal cycler conditions.

PCR results indicated the ability of 4 Aeromonas hydrophila isolates to grow on TCBS producing yellow colonies which was in complete agreement with Buller [33], Bridson [34] and Dworkin et al. [35], they indicated the ability of some Aeromonas hydrophila strains to grow on TCBS producing small yellow colonies. The PCR results also assert the ability of three Vibrio isolates to grow on Rimler-Shotts media, the three isolates were PCR negative for genus aeromonas and positive for genus Vibrio, one of them identified as Vibrio cholera and other two identified as Vibrio alginolyticus. Davis and Sizemore [36] and Arcos et al. [37] reported the ability of Vibrio alginolyticus to grow on Rimler-Shotts media. The current research results indicated non-selectivity of both Rimler-Shotts and TCBS media for isolation Aeromonas and Vibrio species from diseased fish and proved the inevitable need for other diagnostic techniques as PCR.

Current work refered the similarity between different isolated bacteria colonies color on specific media (R-S and TCBS) to the biochemical characters of each recovered bacterial species. On R-S media Aeromonas hydrophila ferment maltose that increase the $\mathrm{pH}$ to acidic side that subsequently turns bromthymol blue to yellow color, Vibrio cholera and Vibrio alginolyticus also ferment maltose producing similar change in media color to yellow, but the role of antibiotic substance (novobiocin) present in R-S media is to prevent the growth of any microorganisms other than aeromonas, but if Vibrio cholera and Vibrio alginolyticus resist novobiocin they can grow producing yellow color colonies similar to that of Aeromonas hydrophila, Rahim and Aziz [38] recorded resistance of $82 \%$ of toxogenic and $75 \%$ of non toxogenic Vibrio cholera strains isolated from water to novobiocin, and this support our point of view. On the other hand, Vibrio cholera and Vibrio alginolyticus can grow on TCBS giving yellow colonies as they ferment sucrose producing acid that decrease $\mathrm{pH}$ which makes bromthymol blue turn yellow color, this media depends on the presence of ox bile in inhibition of another bacteria growth. Current research documents the ability of some strains of Aeromonas hydrophila to grow on TCBS media giving yellow colonies, this can be explained by the ability of such microorganism to grow in the presence of bile and this suspect is supported by the ability of Aeromonas hydrophila to induce enteritis, moreover Aeromonas hydrophila has the ability to ferment sucrose as mentioned by Cipriano et al. [9] the produced acid shifts the $\mathrm{pH}$ to acidic side developing yellow color on TCBS media.

Thirty bacterial isolates were recovered from diseased fish samples (Table 3), Aeromonas hydrophyla represent $63.3 \%$ of total isolated pathogens, it considered one of the most important bacterial pathogens affecting cultured freshwater fish particularly tilapia inducing motile

Table 3: Total number and percent of each recovered bacterial isolates.

\begin{tabular}{|c|c|c|}
\hline Recovered bacteria & Number of isolates & Percent (\%) \\
\hline Aeromonas hydrophila & 19 & 63.33 \\
\hline Vibrio angiolyticus & 3 & 10 \\
\hline Vibrio cholera & 7 & 23.33 \\
\hline $\begin{array}{c}\text { Other bacteria (not } \\
\text { identified) }\end{array}$ & 1 & 3.33 \\
\hline
\end{tabular}

Aeromonas septicemia [9,39]. Ten Vibrio isolates represent $33.3 \%$ of isolated bacterial pathogens, $23.3 \%$ of them were identified as Vibrio cholera and $10 \%$ were Vibrio alginolyticus. Vibrio spp, which are considered a significant problem affecting aquaculture worldwide $[40,41]$. Vibrio alginolyticus and Vibrio cholerae are major pathogens in Chinese aquatic products [15]. Senderovich et al. [42] isolated Vibrio cholera from Oreochromis aureus; Rehulka et al. [43] isolated pathogenic Vibrio cholerae non-O1/non-O139 from moribund freshwater fish, and proved its ability to induce disease condition through experimental infection of common carp, infected carb developed typical signs of Vibriosis. Unidentified pathogenic bacteria represent 3.3\% (one out of 30 isolates).

\section{Conclusion}

In conclusion, the disease condition affecting studied farms was induced by Gram negative bacterial pathogens including Aeromonas hydrophila, Vibrio angiolyticus and Vibrio cholera that represent (96.6\%) of total isolates. Isolation and identification of bacterial fish pathogens depending on culture characters on specific media is inadequate as current research proves non-selectivity of R-S to Aeromonas hydrophyla and TCBS media for Vibrio sp. Isolated from fish, so polymerase chain reaction identification is inevitable.

\section{References}

1. FAO (2016) The State of World Fisheries and Aquaculture. Rome, Italy.

2. GAFRD (2016) Fish Statistics yearbook 2014, General Authority for Fish Resources and Development, Ministry of Agriculture, Cairo, Egypt.

3. Subasinghe RP, Bondad-Reantaso MG, McGladdery SE (2001) Aquaculture development, health and wealth. Aquaculture in the third millennium. Technical Proceedings of the Conference on Aquaculture in the Third Millennium, Rome, Italy.

4. Aboyadak IM, Ali NGM, Goda AMAS, Aboelgalagel WH, Salam AME (2015) Molecular detection of Aeromonas hydrophila as the main cause of outbreak in tilapia farms in Egypt. J Aquacul Mar Biol 2: 5

5. Zhang D, Xu DH, Shoemaker C (2016) Experimental induction of motile Aeromonas septicemia in channel catfish (Ictalurus punctatus) by waterborne challenge with virulent Aeromonas hydrophila. Aquaculture Reports 3: 18-23.

6. Olugbojo JA, Ayoola SO (2015) Comparative studies of bacteria loads in fish species of commercial importance at aquaculture unit and lagoon front of the University of Lagos. J of Fish and Aqua 7: 37-46.

7. Darak O, Barde RD (2015) Pseudomonas fluorescens associated with bacterial disease in Catla catla in Marathwada region of Maharashtra. Int J Adv Biotechnol Res 6: 189-195.

8. Thune RL, Stanley LA, Copper RK (1993) Pathogenesis of gram-negative bacterial infection in warm water fish. Ann Rev Fish Dis 3: 37-68.

9. Cipriano RC, Bullock GL, Pyle SW (2001) Aeromonas hydrophila and motile Aeromonad septicemias of Fish (Fish Disease Leaflet 68), US Department of the Interior Fish and Wildlife Service Division of Fishery Research Washington DC.

10. AOAD (2005) Study on fish diseases in Arab countries (in Arabic). Arab Organization for Agricultural Development publication. Khartoum, Sudan.

11. Lewbart GA (2008) Bacterial diseases of pet fish. Proceedings of Michigan Veterinary Conference, Michigan, USA.

12. Austin B, Austin DA (2012) Bacterial fish pathogens, Disease of farmed and wild fish (5th edn). Springer Dordrecht Heidelberg, New York, London.

13. Noga EJ (2010) Fish disease diagnosis and treatment. (2nd edn), Blackwell Publishing, USA

14. Yanong RPE, Floyd FR (2002) Streptococcal infections of fish. Report from University of Florida (Report No. 57). Series from the Department of Fisheries and Aquatic Sciences, Florida Cooperative Extension Service. Institute of Food and Agricultural Sciences, University of Florida, Florida.

15. Wei S, Zhao H, Xian Y, Hussain M, Wu X (2014) Multiplex PCR assays for the detection of Vibrio alginolyticus, Vibrio parahaemolyticus, Vibrio vulnificus, and Vibrio cholerae with an internal amplification control. Diagn Microbiol Infect Dis 9: 115-118. 
Citation: Aboyadak IM, Ali NGM, Goda AMAS, Saad W, Salam AME (2017) Non-Selectivity of R-S Media for Aeromonas hydrophila and TCBS Media for Vibrio Species Isolated from Diseased Oreochromis niloticus. J Aquac Res Development 8: 496. doi: 10.4172/2155-9546.1000496

16. Sebastião FA, Furlan LR, Hashimoto DT, Pilarski F (2015) Identification of bacterial fish pathogens in Brazil by direct colony PCR and 16S rRNA Gene Sequencing. Adv Microbiol 5: 409-424.

17. Heil N (2009) National wild fish health survey- laboratory procedures manual, (5th edn). US Fish and Wildlife Service, Warm springs, GA, USA.

18. Ahmed AM, Motoi Y, Sato M, Maruyama A, Watanabe $H$ (2007) Zoo animals as a reservoir of gram-negative Bacteria Harboring Inte-grones and Antimicrobial Resistance Genes. Appl Environ Microbiol 73: 6686-6690.

19. Lee C, Cho JC, Lee SH, Lee DG, Kim SJ (2002) Distribution of Aeromonas spp. as identified by $16 \mathrm{~S}$ rDNA restriction fragment length polymorphism analysis in a trout farm. J Appl Microbiol 93: 976-985.

20. Trakhna F, Harf-Monteil C, Abdelnour A, Maaroufi A, Gadonna-Widehem $P$ (2009) Rapid Aeromonas hydrophila identification by TaqMan PCR assay: comparison with a phenotypic method. Lett Appl Microbiol 49: 186-190.

21. De Ocenda VR, Almeida-Prieto S, Luzardo-Álvarez A, Barja JL, Otero-Espinar FJ, et al. (2016) Pharmacokinetic model of florfenicol in turbot (Scophthalmus maximus): establishment of optimal dosage and administration in medicated feed. J Fish Dis 40: 411-424.

22. Asaad TMA (2011) Further studies on Aeromonas hydrophila isolates recovered from fish. Alexandria University, Alexandria, Egypt.

23. Zakaria AA (2014) Molecular characterization of Aeromonas hydrophila strains isolated from diseased marine and freshwater fish. Kafrelsheikh University, Kafrelsheikh, Egypt.

24. Laith AR, Najiah M (2013) Aeromonas hydrophila: Antimicrobial susceptibility and histopathology of isolates from diseased catfish, Clarias gariepinus (Burchell). J Aqua Res Dev 5: 215.

25. Chen CY, Chao CB, Bowser PR (2006) Infection of tilapia Oreochromis species by Vibrio vulnificus. J Worl Aquacult Soc 37: 82-88

26. Okasha LA, Ammar A, El-Hady MA, Samir A, Samy AA, et al. (2016) Identification of common fish bacterial pathogens in Kafr El Sheikh governorate, Egypt using PCR. Int J Biol Pharm Allied Sci 5: 522-537.

27. Janda JM, Abbott SL (2010) The genus Aeromonas: Taxonomy, pathogenicity, and infection. Clin Microbiol Rev 23: 35-73.

28. Aboyadak IMI (2011) A study on the role of antibiotics in controlling Aeromonas hydrophila infection in cultured freshwater fish. Kafrelsheikh University, Kafrelsheikh, Egypt.

29. Yamanoi H, Muroga K, Takahashi S (1980) Physiological characteristics and pathogenicity of NAG vibrio isolated from diseased ayu. Fish Pathol 15: 69-73.
30. Ascencio F, Aleljung P, Wadstrom T (1990) Particle agglutination assays to identify fibronectin and collagen cell surface receptors and lectins in Aeromonas and Vibrio species. Appl Environ Microbiol 56: 1926-1931.

31. Li J, Zhou L, Woo NYS (2003) Invasion routes and pathogenicity mechanisms of Vibrio alginolyticus to silver sea bream Sparus sarba. J Aquat Anim Health 15: $302-313$

32. Wei S, Xian Y, Zhao H, Wu X (2013) Simultaneous Detection of Vibrio alginolyticus, Vibrio parahaemolyticus, Vibrio vulnificus and Vibrio Cholera using multiplex PCR. Scientia Agricultura Sinica 46: 1682-1686.

33. Buller NB (2004) Bacteria from fish and other aquatic animals, A practical identification manual. CABI Publishing, UK.

34. Bridson EY (2006) The OXOID Manual. Published by OXOID Limited, Wade Road, Basingstoke, Hampshire, England.

35. Dworkin M, Falkoe S, Rosenberg E, Schleifer KH, Stackebrandt E (2006) A Handbook on the Biology of Bacteria, Volume 6: Proteobacteria: Gamma Subclass, third Edition. Springer Science and Business Media, LLC, 233 Spring Street, New York, USA.

36. Davis JW, Sizemore RK (1981) Non-selectivity of Rimler-Shotts Medium fo Aeromonas hydrophila in Estuarine Environments. Appl Environ Microbiol 42 544-545.

37. Arcos ML, De Vicente A, Morinigo MA, Romero P, Borrego JJ (1988) Evaluation of several selective media for recovery of Aeromonas hydrophila from polluted waters. Appl Environ Microbiol 54: 2786-2792.

38. Rahim Z, Aziz KMS (1992) Isolation of enterotoxogenic Vibrio cholera nonO1 from the Buriganga river and two ponds of Dhaka, Bangladesh. J Diarr Diseas Res 10: 227-230.

39. Furmanek-Blaszk B (2014) Phenotypic and molecular characteristics of an Aeromonas hydrophila strain isolated from the River Nile. Microbiol Res 169 : 547-552.

40. Chatterjee S, Haldar S (2012) Vibrio related diseases in aquaculture and development of rapid and accurate identification methods. J Mar Sci Res Develop S1:002

41. Haenen OLM, Fouz B, Amaro C, Isern MM, Mikkelsen H, et al. (2014) Vibriosis in aquaculture (Workshop report). Bulletin European Association of Fish Pathologists 34: 138.

42. Senderovich Y, Lzhaki I, Haloperm M (2010) Fish as reservoirs and vectors of Vibrio cholera. PLoS ONE 5: e8607.

43. Rehulka J, Petras P, Marejkova M, Aldova E (2015) Vibrio cholerae non-O1 non-0139 infection in fish in the Czech Republic. Veterinarni Medicina 60: 16-22. 